\title{
Correction to: Protective effect of $p$-methoxycinnamic acid, an active phenolic acid against 1,2-dimethylhydrazine-induced colon carcinogenesis: modulating biotransforming bacterial enzymes and xenobiotic metabolizing enzymes
}

Sivagami Gunasekaran ${ }^{1} \cdot$ Karthikkumar Venkatachalam ${ }^{1} \cdot$ Kabalimoorthy Jeyavel $^{2} \cdot$ Nalini Namasivayam $^{1}$

Published online: 29 March 2021

(c) Springer Science+Business Media, LLC, part of Springer Nature 2021

\section{Correction to: \\ Molecular and Cellular Biochemistry (2014) 394:187-198 \\ https://doi.org/10.1007/s11010-014-2094-3}

The original publication of the article includes error in Fig. 5. The correct version of Fig. 5 is provided in this correction.

The original article can be found online at https://doi.org/10.1007/ s11010-014-2094-3.

Nalini Namasivayam

nalininam@yahoo.com

1 Department of Biochemistry and Biotechnology, Faculty of Science, Annamalai University, Annamalainagar 608 002, Tamilnadu, India

2 Department of Surgery, Faculty of Medicine, Annamalai University, Annamalainagar 608 002, Tamilnadu, India 
Fig. 5 Topographical view of normal crypts and DACF in the colon of control and experimental rats. A Colon of control rats (group 1) showing normal crypts $(20 \times)$. B Colon of p-MCA control rats (group 2) showing normal crypts (20x). C Colon of DMH-treated rats (group 3) showing DACF ( $\nearrow$ ) with multiple (ten) crypts (40×). D Colon of DMH+pMCA-treated rats $(20 \mathrm{mg} / \mathrm{kg}$ b.wt, group 4) showing DACF $(\nearrow)$ with five crypts $(20 \times)$. $\mathbf{E}$ Colon of DMH+p-MCA treated rats $(40 \mathrm{mg} / \mathrm{kg}$ b.wt, group 5) showing normal crypts $(20 \times)$. F Colon of DMH+p-MCA-treated rats $(80 \mathrm{mg} / \mathrm{kg}$ b.wt, group 5) showing DACF $(\nearrow)$ with five crypts $(20 \times)$
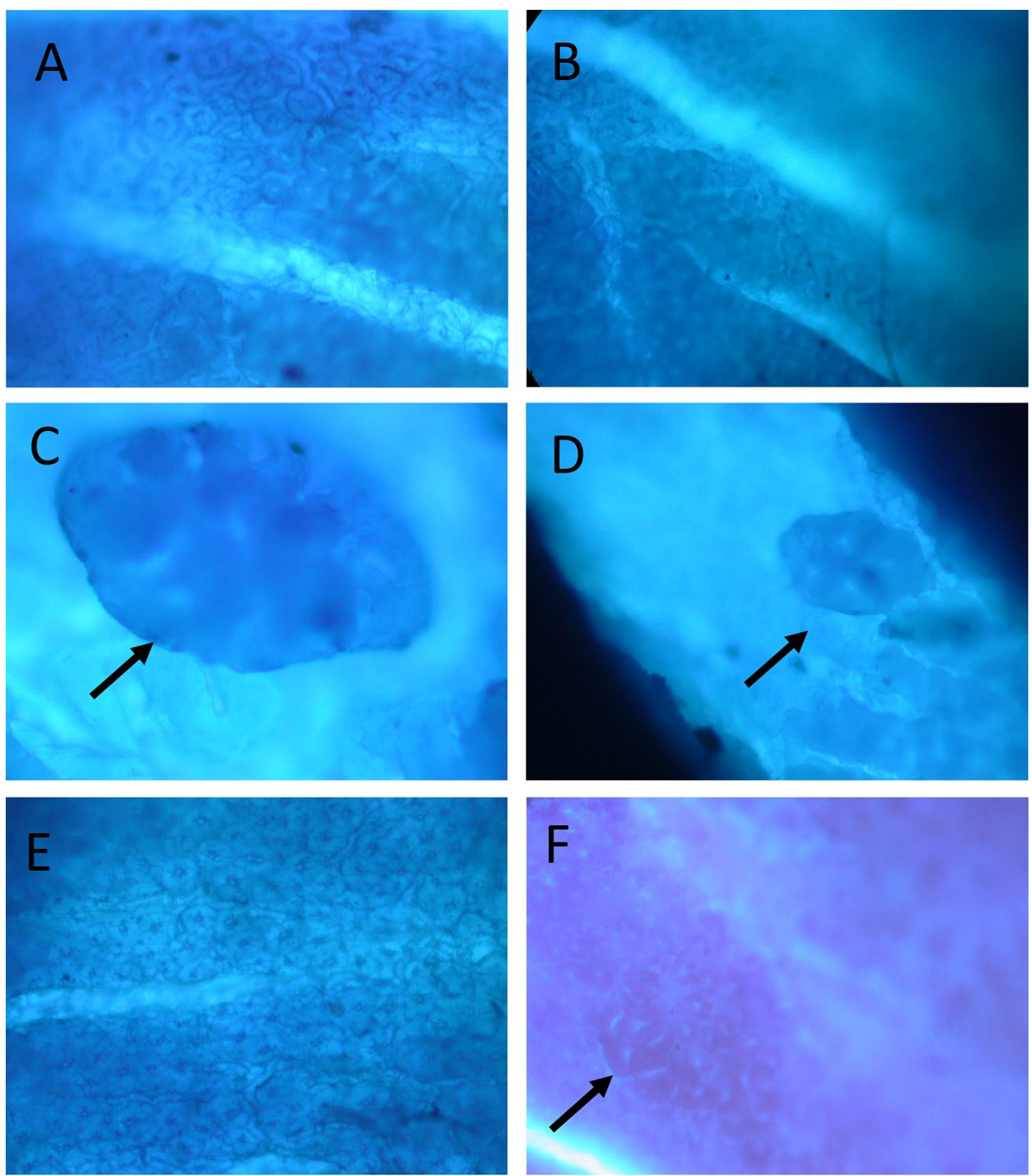

Publisher's Note Springer Nature remains neutral with regard to jurisdictional claims in published maps and institutional affiliations. 